\title{
Ecosystem-Based Management (EBM) and Ecosystem Services in EU Law, Policy and Governance
}

\author{
Anne Marie O’Hagan
}

\begin{abstract}
Ecosystem-Based Management has become the dominant desired paradigm for environmental management globally yet what it entails and how it can be implemented presents many challenges. This chapter seeks to set out the legal bases for Ecosystem-Based Management (EBM) and Ecosystem Services in EU law and policy frameworks. It traces both concepts with a view to establishing how their legal status internationally and regionally has influenced their uptake within national governance frameworks. The rationale for EBM is to manage resources in a way that maintains the health of the ecosystem alongside appropriate human use of the marine environment, for the benefit of current and future generations, and accordingly is intrinsic to achieving sustainable development. EBM therefore represents two keys challenges for existing governance systems: firstly, the need to move away from sectoral based management and towards more integrated approaches and secondly, to embed the notion of 'healthy' ecosystems into all law and policy instruments. The chapter begins with the international and regional levels of governance and how both approaches have been incorporated. It then proceeds to a brief overview of the EU legal system, examines the key elements of biodiversity policy and conclude with a discussion and conclusions on whether these have enabled the implementation of EBM and ecosystem services.
\end{abstract}

\section{Lessons Learned}

- There is no definition of EBM or ecosystem services in EU law.

- EBM necessitates a move away from traditional sectoral focussed management as policy-makers need to manage for multiple ecosystem services that cannot be achieved if a single sectoral or policy 'lens' is taken.

- Regional Conventions have been instrumental in developing understanding of EBM and ES but can be limited by their individual remits.

\footnotetext{
A. M. O’Hagan ( $\triangle)$

MaREI: The SFI Research Centre for Energy, Climate and Marine, Environmental Research Institute: Beaufort Building, University College Cork, Cork, Ireland

e-mail: a.ohagan@ucc.ie
} 
- In the EU, EBM is partially implemented and in a top-down manner giving Member States significant discretion and often resulting in extensive differences between countries.

- Many existing EU policies in their current form contradict the commitment to implementing EBM and preserving ecosystem services, such as measures and activities under Common Agricultural Policy and Common Fisheries Policy.

\section{Needs to Advance EBM}

- There is a need for clear definition and agreement on what EBM is and how it can be implemented in practice at EU and national levels.

- EBM also necessitates adaptive management in order to deal with dynamic ecosystems and the absence of complete knowledge or understanding of their functioning.

- There is a critical need for clarity on what EBM actually requires, on how implementation progress can be measured and sharing of successful 'better' EBM practices.

\section{Introduction to Ecosystem-Based Management (EBM) and Ecosystem Services (ES) in International Law and Policy}

Somewhat surprisingly, there is no universally accepted definition of EcosystemBased Management (EBM) or the ecosystem approach in international or EU law, yet this has not limited implementation efforts to date. Aspects of the ecosystem approach can be traced back to the Stockholm Declaration on the Human Environment in 1972, which called for cooperation on conservation, protection and restoration of the Earth's ecosystem (United Nations 1972). The two key international legal instruments of relevance to EBM and ES are the UN Convention on Biological Diversity and the UN Convention on the Law of the Sea.

\subsection{UN Convention on Biological Diversity (CBD)}

The Ecosystem Approach was adopted as the primary framework for the conservation and sustainable use of biodiversity under the Convention on Biological Diversity (CBD) in 1995 hence it is from the CBD that the most widely used definition is derived. The fifth Conference of the Parties describes the Ecosystem Approach as "a strategy for the integrated management of land, water and living resources that promotes conservation and sustainable use in an equitable way" (CBD 2000). It went further to state that it "requires adaptive management to deal with the complex and dynamic nature of ecosystems and the absence of complete knowledge or understanding of their functioning". Implementation of the Ecosystem Approach is 
facilitated through 12 interlinked principles, known as the Malawi Principles (see Enright and Boetler 2020). Whilst the term 'ecosystem services' was not in use when the CBD was endorsed, the concept is implicit in the Convention text. Principle 5 goes some way towards explaining how the Ecosystem Approach and ecosystem services are connected: "conservation of ecosystem structure and functioning, in order to maintain ecosystem services, should be a priority target of the ecosystem approach", with a focus on ecosystem functioning.

The Malawi Principles provide the context for further action and, at the tenth Conference of the Parties, a global Strategic Plan for Biodiversity 2011-2020 was adopted. The plan's mission is "to take effective and urgent action to halt the loss of biodiversity in order to ensure that by 2020 ecosystems are resilient and continue to provide essential services, thereby securing the planet's variety of life, and contributing to human well-being, and poverty eradication". This means that the CBD provides the global framework for regional and national action to protect biodiversity but also the services that biodiversity provides. The Strategic Plan includes the Aichi Biodiversity Targets on the management of protected areas and the conservation of all ecosystems through the application of the precautionary approach and the Ecosystem Approach. The Aichi Biodiversity Targets consist of five Strategic Goals each of which are accompanied by specific targets. The goal on improving the status of biodiversity by safeguarding ecosystems, species and genetic diversity, for example, is the basis for Target 11 on conservation designations: "by 2020, at least 17 per cent of terrestrial and inland water, and 10 per cent of coastal and marine areas, especially areas of particular importance for biodiversity and ecosystem services, are conserved through effectively and equitably managed, ecologically representative and well-connected systems of protected areas and other effective area-based conservation measures, and integrated into the wider landscapes and seascapes" (CBD 2010). Ecosystem services are also addressed directly by Strategic Goal D: "Enhance the benefits to all from biodiversity and ecosystem services" which includes Target 14: "By 2020, ecosystems that provide essential services, including services related to water, and contribute to health, livelihoods and wellbeing, are restored and safeguarded, taking into account the needs of women, indigenous and local communities, and the poor and vulnerable."

\subsection{United Nations Convention on the Law of the Sea (UNCLOS)}

The Law of the Sea Convention defines the rights and responsibilities of nations with respect to their use of the world's oceans, protection of the marine environment, and the management of marine natural resources. There is no mention of the Ecosystem Approach in the Convention though debatably, the approach is included implicitly as it contains an absolute obligation to protect and preserve the marine environment (Article 192) and to adopt measures to protect and preserve rare or fragile 
ecosystems as well as the habitat of depleted, threatened or endangered species and other forms of marine life (Article 194(5)). Both these provisions, however, require further implementation mechanisms at national level in order to be achieved. The 1995 Fish Stocks Agreement ${ }^{1}$ establishes an obligation for States to protect marine biodiversity via the protection of target and non-target species as well as the ecosystems associated with those species. The Agreement also includes a duty to cooperate in Regional Fisheries Management Organisations (RFMOs) or similar arrangements in an effort to recognise the transboundary nature of aquatic biodiversity and need for concerted coordinated action. Alas this remains a key challenge as the existing RFMOs do not cover all ocean space and organise their work according to geographic area and specific fish species meaning that many areas and species remain ineffectively managed. The links between the CBD and UNCLOS are recognised under CBD's Article 22(2) which provides that Parties will implement the $\mathrm{CBD}$ with respect to the marine environment "consistently with the rights and obligations of States under the Law of the Sea". 2

\subsection{OSPAR Convention}

At the regional level, application of the Ecosystem Approach can be found in many of the Regional Seas Conventions and their associated mechanisms. The OSPAR Convention, for example, provides a framework for the regulation of almost all human activities ${ }^{3}$ that have an adverse effect on marine ecosystems and biodiversity in the North-East Atlantic. The Helsinki and OSPAR Commissions adopted a statement on how the EA could be implemented under their respective legal instruments. This states that the Ecosystem Approach is "the comprehensive integrated management of human activities based on the best available scientific knowledge about the ecosystem and its dynamics, in order to identify and take action on influences which are critical to the health of marine ecosystems, thereby achieving sustainable use of ecosystem goods and services and maintenance of ecosystem integrity" (Helsinki and OSPAR Commissions 2003). The OSPAR Commission's work is guided by the Ecosystem Approach and it is implemented in the North-East Atlantic by means of the programmes and measures developed under OSPAR's six

\footnotetext{
${ }^{1}$ Agreement for the Implementation of the Provisions of the UN Convention on the Law of the Sea of 10 December 1982 relating to the Conservation and Management of Straddling Fish Stocks and Highly Migratory Fish Stocks, 4 August 1995 (into force 11 December 2001) 2167 UNTS 3.

${ }^{2}$ An exception to this is provided in Article 22(1) whereby "CBD provisions shall not affect the rights and obligations of any Party deriving from any international agreement except where the exercise of those rights and obligations would cause a serious damage or threat to biological diversity".

${ }^{3}$ Except fisheries and pollution from ships.
} 
thematic Strategies. ${ }^{4}$ The International Council for the Exploration of the Seas (ICES), working with OSPAR and HELCOM, has been instrumental in developing a better understanding of the EA and providing guidance and recommendations on how it can be implemented (e.g. ICES 2005). This includes the identification of practical steps in applying the approach by those tasked with implementing marine policy in the EU and informed the design of the EU's Marine Strategy Framework Directive. Unfortunately, by design, the Regional Seas Convention bodies are limited in the actions they can take in implementing the EA due their pre-defined geographical area and remit for actions.

Essentially the rationale for EBM is that whilst the ecosystem itself may not be managed, the human uses and activities that interact and impact upon the ecosystem may be managed so as to conserve biodiversity and ensure sustainable development (Long 2012). Ultimately the aim is to preserve ecosystem structure and functioning so as to ensure the ongoing provision of products and services. Therefore, management of the impacts of human activities must focus on the entire ecological system and not its component parts. This necessitates a move away from traditional sectoral management approaches towards those that are integrated, adaptive and coherent across policy domains so as to take account of social, economic and environmental aspects. EBM recognises that new forms of valuation and assessment are needed, and that different sectors of society will view ecosystems from their own environmental, economic and societal needs. The role of ecosystem services therefore is to provide information on the values and services that flow from ecosystems to humans. Internationally, the Millennium Assessment (MA) and The Economics of Ecosystems and Biodiversity (TEEB) initiatives have sought to capture information on the value of and benefits from ecosystems in a format that can be used by policy and decision-makers.

\section{EBM and ES in EU Law and Policy}

Whilst EBM is not expressly mentioned in the European treaties, under Article 11 of the Treaty on the Functioning of the EU, there is a duty to integrate environmental protection into the definition and implementation of EU policies "in particular with a view to promoting sustainable development". Article 191 TFEU states that EU environmental policy should promote measures at international level to deal with regional or worldwide environmental problems, which could be interpreted to include EBM. Essentially EBM (or the Ecosystem Approach) is introduced and implemented in the EU in a top-down fashion through a wide range of Directives and policy documents, resulting in much national autonomy in terms of implementation. The EU Biodiversity Baseline found that only $17 \%$ of habitats and species and 11\%

\footnotetext{
${ }^{4}$ Biodiversity, eutrophication, radioactive substances, hazardous substances, offshore industry and assessment/monitoring.
} 
of key ecosystems protected under EU legislation were classified as being in a favourable state (EEA 2010). In an attempt to address reverse this loss and assist in becoming a more resource efficient and green economy, the EU adopted a biodiversity strategy in 2011 .

\subsection{Biodiversity Law and Policy}

The EU Biodiversity Strategy 2020 aims to implement the CBD's Strategic Plan for Biodiversity 2011-2020 and the Aichi Targets (European Commission 2011). It recognises the role that biodiversity plays in underpinning the economy and the services it provides. The strategy sets out six targets to achieve the over-arching 2020 target of "halting the loss of biodiversity and the degradation of ecosystem services in the EU by 2020, and restoring them in so far as feasible, while stepping up the EU contribution to averting global biodiversity loss". The targets relate to nature (target 1), ecosystems and their restoration (target 2), the sustainable use of Europe's nature, land and sea resources via agriculture, forestry and fisheries (targets 3 and 4), alien species (target 5) and the EU's global impacts (target 6). A mid-term review of the Biodiversity Strategy was conducted in 2015 and found that biodiversity loss and degradation of ecosystem services in the EU has continued and, whilst some progress has been made at the policy level, this has not yet halted the trend of degradation of ecosystems and services (European Commission 2015a). The review concludes by stating that the 2020 biodiversity targets will only be achieved if implementation and enforcement efforts become "considerably bolder and more ambitious." An associated Fitness Check of the Birds and Habitats Directive, as the cornerstones of biodiversity policy in the EU, evaluated these instruments in terms of their effectiveness, efficiency, relevance, coherence and EU added value (European Commission 2016a). In terms of effectiveness, the evaluation found that the general objectives of the Directives have not yet been met and that it was not possible to predict when the objectives would be fully achieved but acknowledged that improvements in the status of species and habitats occur where there are targeted actions at a sufficient scale.

The Biodiversity Strategy is complemented by a wide range of legal instruments including the Birds and Habitats Directives, the Water Framework Directive, the Marine Strategy Framework Directive and the EU Regulation on Invasive Alien Species (No. 1143/2014). These four Directives, and one Regulation, provide the legal basis to protect aquatic biodiversity across the freshwater-marine continuum and hence seek to enable implementation of EBM. Bastmeijer (2019) states that the Birds and Habitats Directive are not based on the ecosystem approach and Rouillard et al. (2018) state neither Directive explicitly mentions ecosystem services or takes them into account implicitly. Despite this they are essential in protecting certain types of biodiversity. The Birds Directive provides for the designation of sites for the protection of bird species listed in Annex I, along with the designation of sites designated for "regularly occurring migratory species not included in Annex I" 
under Article 3(2). This is complemented by the Habitats Directive which, under Article 3(1), requires Member States to select and designate "sites hosting the natural habitat types listed in Annex I and habitats of the species listed in Annex II". Together the protected sites designated under each Directive form the Natura 2000 network, the largest global network of protected areas, which seeks to achieve the objective of maintaining or restoring natural habitats and species of Community interest at Favourable Conservation Status. The Appropriate Assessment procedure under Article 6, determines whether a plan or project can be implemented without damaging a Natura 2000 site, through an examination of the implications of a proposed development for the Natura 2000 site and its conservation objectives. Though this can add to regulatory and consenting requirements, the majority of plans and programmes subjected to this assessment are permitted to proceed (European Commission 2016a).

The Invasive Alien Species Regulation (IAS, No. 1143/2014) is mentioned here as it is the only EU legal instrument to explicitly contain a definition of ecosystems services as "the direct and indirect contributions of ecosystems to human wellbeing" in Article 3(6), perhaps attributable to its relatively recent entry into force (2015) when compared to other biodiversity instruments. It consists of three types of measures: prevention; detection and eradication; and management measures, based on the list of IAS of Union Concern contained within the Regulation. This list is updated regularly commencing with a proposal from a Member State or the EC, supported by a risk assessment; followed by an expert evaluation of the available evidence and inputs from a range of stakeholders and the Member States. This proposal must then be approved by a Committee comprised of Member States' representatives before final adoption by the Commission. There are no timelines associated with this process. Bouwma et al. (2018) state the IAS Regulation requires that its effectiveness on biodiversity, ecosystem services and, human health and the economy, if applicable, is monitored though the development of concrete measures and comprehensive action plans to prevent the "unintentional introduction and spread of invasive alien species" is left up to Member States. There is no dedicated funding instrument associated with the IAS though actions have been supported by the Commission through Horizon 2020, LIFE+, the rural development programme and other funding programmes such as Interreg. ${ }^{5}$

The European Commission (2007) has stated that the implementation of the Natura 2000 network forms one of the legal components to implementing the ecosystem approach in the marine environment. The mid-term review of the Biodiversity Strategy, states that the Natura 2000 network now covers approximately 18\% of land but marine coverage is much lower at $6 \%$, well below the $10 \%$ Aichi target. This could be attributed to the fact that there are much less marine species and

\footnotetext{
${ }^{5}$ The Interreg IVA programme, for example, funded the INVEXO project to support joint management efforts on four priority invasive alien species in Flanders and southern part of the Netherlands.
} 
habitats listed in the Annexes of both Directives. ${ }^{6}$ Marine species are also more difficult to protect in the same manner as terrestrial species as the marine species concerned may have a wider geographic range, perhaps taking in multiple jurisdictions. The EEA (2015a) concluded that only $21 \%$ of the habitat assessments and $23 \%$ of the non-bird species assessments were at favourable conservation status and $52 \%$ of the bird species assessed were secure, based on the reporting required under both Directives between 2007 and 2012. The same report (p. 8) states that the most frequently cited pressures and threats for marine ecosystems are fishing, modification of natural conditions and pollution. This brings into focus the need for greater interplay between the nature conservation Directives and other thematic legislation, not only to better protect the environment, but to implement the ecosystem approach. This is echoed by the EC's mid-term review of the EU's Biodiversity Strategy (2015a) which notes that "a lot remains to be done to halt the loss of ordinary biodiversity outside the Natura 2000 network." A key consideration in this context is the costs associated with implementation. The Fitness Check (EC 2016a, p. 5) states that as Member States do not have to report on the costs and benefits of the nature conservation legislation, there is limited quantitative information available at the EU scale to underpin assessments on efficiency and that "compliance costs of designating, protecting and managing Natura 2000 sites have been estimated to be at least $€$ 5.8 billion annually across the EU."

\subsection{Water Law and Policy}

Alongside the nature conservation Directives, the Water Framework Directive (WFD) seeks to prevent the deterioration of freshwater ecosystems and restore their good ecological status. The Marine Strategy Framework Directive (MSFD), adopted slightly later in 2008, aims to achieve good environmental status of EU marine waters by 2020 . The Directives therefore provide an ecological continuum from a river basin to the sea and, by taking a cyclical approach to implementation, should enable an adaptive management approach, one of the fundamental principles of EBM. The WFD was the first EU legal instrument to adopt a holistic approach to aquatic regulation via a move away from management on the basis of administrative boundaries. Evaluation of water quality under Annex V of the WFD requires consideration of the quality of the structure and functioning of aquatic ecosystems (surface waters), the physical-chemical nature of the water and sediment, the flow characteristics of the water, and the physical structure of water bodies. Article 4 of the Directive contains exemptions from the ecological goals, either by way of force majeure, reasons of overriding public interest or lack of ability of the Member State to achieve the goals due to external factors (e.g. impacts from other States). Whilst

\footnotetext{
${ }^{6}$ There are nine marine habitat types and 16 species listed in the Habitats Directive, and 60 bird species listed in the Birds Directive.
} 
elements of the Directive are based on physical, chemical and biological parameters, the River Basin Management Plans, required under the Directive must also consider the socio-economic environment of the region and all activities that might impact on the status of a water body. A fitness check of the WFD (EC 2012) recommended that greater consideration be given to ecosystem services in the Directive, its Common Implementation Strategy and other policies "so that they can be better reflected in the implementation on the ground."

The Marine Strategy Framework Directive (MSFD) primarily aims to prevent any further deterioration of the marine environment, recognising it is the basis of the blue economy or, in other words, recognising the ecosystem services the marine environment provides. The Directive tries to better integrate the concepts of environmental protection and sustainable use. The MSFD was also viewed by the European Commission (2005) as a way of addressing sectoral fragmentation in marine governance and attaining the international obligations the EU had in terms of biodiversity under the CBD and Regional Seas Conventions to which the EU is a party. The MSFD requires in Article 1(1) that EU Member States to "take the necessary measures to achieve or maintain good environmental status in the marine environment by the year 2020 at the latest." According to Article 3(5), this objective is to be achieved by applying "adaptive management on the basis of the ecosystem approach." It is clear, from the 11 descriptors used in the Directive, that the concept of "good environmental status" includes the conservation of biodiversity and the maintenance of ecosystem health and integrity. The descriptors have since been supplemented in an European Commission Decision (2010) which subdivided them into 29 criteria and 56 associated 'indicators' so as to determine more precisely what attributes of the ecosystem features should be considered when assessing environmental status, ultimately with the aim of achieving more uniform assessment. Ecosystem services are only indirectly included in the descriptors. Berg et al. (2015) explain that Descriptor 3, on commercially exploited fish and shellfish, defines criteria on fish demographics aiming to ensure that fish populations are able to be caught (ecosystem service: food provision) and still be viable and productive. They conclude that although the MSFD includes sustainable use of the marine environment as part of the definition of GES, the Decision does not include criteria targeting ecosystem services that can be used to inform on the aspect of sustainable use. Like under the WFD, Member States are required to produce Marine Strategies for marine areas under their sovereignty and jurisdiction which must contain a comprehensive assessment of the state of the marine environment, a definition of "GES" at the regional level, clear environmental targets and monitoring programmes.

Subsequent to the initial assessment, setting of targets and monitoring plan, Member States must design a programme of measures (POM) to deliver the targets, each measure being supported by a cost-benefit analysis. In designing their POM, Member States are obliged to consult competent authorities in the field of water and nature conservation policy but the involvement of other sectoral authorities is at the discretion of the Member State. Perhaps in recognition of the need to take a broader perspective to implement the Ecosystem Approach, the MSFD advocates that 
operational and implementation measures are adopted through the Regional Seas Conventions. The Programmes of Measures "shall include spatial protection measures, contributing to coherent and representative networks of marine protected areas (MPAs) adequately covering the diversity of the constituent ecosystems" such as SACs, SPAs and other forms of MPAs under the RSCs or other international agreements. Sites in the Natura 2000 network, with marine qualifying interests, are the single largest contributor to European MPAs in terms of coverage, though it is acknowledged that geographic coverage lessens further offshore: Natura 2000 sites covered $33.3 \%$ of nearshore waters, $11.3 \%$ of coastal waters and only $1.7 \%$ of offshore waters (EEA 2015b). The EEA differentiates between three types of MPAs in the EU: marine Natura 2000 sites, MPAs designated under Regional Sea Conventions, and individual national MPAs. The Commission (2015b) has stated that in order for MPAs to fully deliver their potential, they must include management measures and require effective monitoring and enforcement. MPAs will be an integral part of Maritime Spatial Plans, which are legally required by 2021. As the MSFD is intended to make marine regulation and decision-making more integrated in form and content it will influence both cross-cutting management approaches such as Maritime Spatial Planning and Integrated Coastal Management, as well as sectoral policies, such as the Common Fisheries Policy.

\subsection{Sectoral Law and Policy}

\subsubsection{Common Fisheries Policy (CFP)}

As outlined above, to achieve the over-arching objectives of the MSFD, particular marine activities will have to reduce their environmental impacts or plan to mitigate these. One example of this is the requirement to consider the effects of the Common Fisheries Policy (CFP) on GES. ${ }^{7}$ Article 2 of the Basic Fishery Management Regulation (2371/2002) states that one aim of the CFP is "to minimise the impact of fishing activities on marine ecosystems and to ensure the progressive implementation of an ecosystem-based approach to fisheries management.” The European Parliament and Council's 7th Environmental Action Programme (2013), in relation to the exploitation of marine resources, recognises that "care needs to be taken to ensure their exploitation is compatible with the conservation and sustainable management of marine and coastal ecosystems." For GES, Descriptor 3 requires that populations of all commercially exploited fish and shellfish are within safe biological limits, exhibiting a population age and size distribution that is indicative of a healthy stock. It is left up to Member States to decide how to achieve this. Fisheries policy with regard to resource exploitation is an exclusive competence of the EU. The MSFD sets out objectives to be achieved but is unable to subject the CFP to its terms.

${ }^{7}$ Recital 40, MSFD and Article 2(5)(j) of Regulation 1380/2013. 
As such, the MSFD merely notes in Recital 39 that "measures regulating fisheries management can be taken in the context of the Common Fisheries Policy" ... "with a view to supporting the achievement of the objectives addressed by this Directive". A significant weakness however is that there is no requirement for the CFP to conform to or harmonise with the environmental objectives of the MSFD, and no specific measures to ensure coherence, thereby limiting the potential for implementation of an Ecosystem Approach and consideration of ecosystem services in fisheries management.

Article 8 of the revised Fisheries Regulation (No.1380/2013) provides for the creation of fish stock recovery areas, "due to their biological sensitivity, including areas where there is clear evidence of heavy concentrations of fish below minimum conservation reference size and of spawning grounds". ${ }^{8}$ In these areas fishing activities may be restricted or prohibited in order to contribute to the conservation of living aquatic resources and marine ecosystems. ${ }^{9}$ These areas could also contribute to a coherent network of protected areas, as envisaged under the Biodiversity Strategy and CBD. Article 11(1) of the Fisheries Regulation (No.1380/2013) provides that Member States can adopt conservation measures within waters under their jurisdiction in order to comply with their obligations under the MSFD and other EU environmental law provided that such measures do not affect the fishing vessels of other Member States and are compatible with the objectives of the CFP. Where there is a serious threat to the conservation of marine biological resources, or to the marine ecosystem, based on evidence, Article 12 (No.1380/2013) provides that the Commission may adopt restrictive measures for environmental protection that apply to all vessels but, by definition, these are time bound in that they cannot apply for longer than six months and may only be renewed once. This 'supremacy' of fishing can best be explained by its prominence in the EU Treaties, under the agriculture provisions, and in practice means that all Member States would have to agree to any measures likely to impact on or modify fishing activity. The revised governance structure in the 2013 Reform Package aims to address this somewhat by giving Member States more of a role in customising regional conservation measures, specifically on recommendations for achieving the objectives of conservation measures, provided the Commission is of the opinion such recommendations are compatible with the relevant conservation measure and/or applicable multiannual plan. ${ }^{10}$

\footnotetext{
${ }^{8}$ Regulation (EU) No 1380/2013 of the European Parliament and of the Council of 11 December 2013 on the Common Fisheries Policy, amending Council Regulations (EC) No 1954/2003 and (EC) No 1224/2009 and repealing Council Regulations (EC) No 2371/2002 and (EC) No 639/2004 and Council Decision 2004/585/EC. Official Journal of the European Union, L 354, pp. $22-61$.

${ }^{9}$ Article 8(1), Fisheries Regulation (No.1380/2013).

${ }^{10}$ Article 18(3), Fisheries Regulation (No.1380/2013).
} 


\subsubsection{Common Agricultural Policy (CAP)}

The Common Fisheries Policy is largely modelled on the Common Agricultural Policy, one of the common policy areas of the EU, in operation since 1962. As a common policy area the aim is to ensure there is a level playing field and fair competition between farmers. The objectives of CAP are to improve agricultural productivity, ensure a fair standard of living for those involved in farming, stabilise markets, assure the availability of supplies and ensure that produce reaches consumers at reasonable prices. ${ }^{11}$ Reforms to the CAP have expanded it to encourage farmers to provide public goods, enhance biodiversity and help address climate change but not in the official constitutionalised version from the late 1950s. The CAP is financed centrally by the EC through two funds: the European Agricultural Guarantee Fund (EAGF), which provides direct support and funds market measures; and the European Agricultural Fund for Rural Development (EAFRD) which finances rural development programmes. The budget for CAP is €362.8 billion, almost $40 \%$ of the total EU budget, for the period 2014-2020, of which €277.9 billion is foreseen for Direct Payments and market-related expenditure (Pillar 1) and $€ 84.9$ billion is for Rural Development (Pillar 2) (European Commission 2013a). Agricultural nutrient sources are a major contributor to the status of water quality across the EU and needs to be considered as part of an ecosystem approach to aquatic management. The Nitrates Directive, together with the WFD, requires Member States to monitor water quality and, in particular, to identify areas that are polluted or at risk of pollution due to agricultural activities. These areas are known as "Nitrate Vulnerable Zones" and Member States are required to create Nitrate Action Programmes in order to reduce and prevent water pollution. Measures under these programmes include limits in when fertilizers can be applied, requirements for storage of manure, conditions for fertilizer applications, and limits on the amounts of fertilizer that can be used.

The Nitrates Directive does not refer to the Ecosystem Approach or ecosystem services directly though the definition of "pollution" in Article 2(j) acknowledges that pollution can cause "... harm to living resources and to aquatic ecosystems, damage to amenities or interference with other legitimate uses of water", thereby implicitly recognising ecosystem services. Reform of the CAP in 2013 resulted in a new policy instrument of the first pillar (greening) and covers the provision of environmental public goods. The Green Direct Payment equates to $30 \%$ of the national direct payment envelope and recompenses farmers for maintaining permanent grassland, creating ecological focus areas and diversifying crops. A portion of the rural development programme budget (30\%) must also be used for measures that are beneficial for the environment and climate change, such as agri-environmentalclimate measures, organic farming, Areas of Natural Constraints (ANC), Natura 2000 areas and forestry measures. Whilst well-intentioned, these measures have been largely unsuccessful, in terms of biodiversity conservation (Pe'er et al. 2017),

${ }^{11}$ Article 39(1) Article 39 TFEU (ex Article 33 TEC). 
mitigation of climate change (European Commission 2019), and wider public opinion on whether CAP actually does enough to address environmental degradation and climate change (European Commission 2016b). Pe'er et al. (2019) found that highest investments are made into the least effective greening (€789.9/ha), compared to a third as many payments for the more effective agri-environment climate measures ( $€ 247.2 / \mathrm{ha})$ and direct payments continue to be 'coupled' to the production of certain crops and livestock including input-intensive systems such as beef fattening and vegetable production which undermines overall sustainability goals. To achieve these, significant reforms are required not only to the substantive provisions of CAP but also its overall governance and integration with other key policy areas.

\subsection{Cross-cutting Management Approaches}

Integrated marine governance has been a focus area of Commission work since the early 1990s in terms of Integrated Coastal Zone Management (ICZM) and more recently Maritime Spatial Planning (MSP). MSP is seen as essential to delivering the jobs potential provided by maritime sectors, protection of the marine environment and optimisation of the use of marine space. ICZM has a policy basis in the associated Recommendation dating from 2002. ${ }^{12}$ This recommends that Member States protect their coastal environment based on an ecosystem approach "preserving its integrity and functioning". Recognising the need for more action on integrated management approaches, the EC proposed a draft Directive, aimed at creating a framework for both Integrated Coastal Management (ICM) and Maritime Spatial Planning, with a view to improving planning and management of the land-sea interface (European Commission 2013b). During the negotiation phase, however, ICM was dropped from its contents. No official explanation is available but significant concerns were expressed by the Committee of the Regions (2013), for example, as it was perceived that ICM impinged substantially on existing Member State competences relating to spatial planning policy and practice at regional and/or local levels. The MSP Directive (2014/89/EU) was adopted in July 2014 and necessitates Member States to establish their first Maritime Spatial Plans by 31 March 2021. Article 5(1) requires Member States to apply an ecosystem-based approach when establishing and implementing MSP. The substantive provisions of the Directive say nothing further on the ecosystem-based approach though Recital 14 could be said to add some clarity saying the aim of applying an ecosystem approach is to ensure that the collective pressure of all activities is kept within levels compatible with the achievement of GES under MSFD and "that the capacity of marine ecosystems to respond to human-induced changes is not compromised, while

\footnotetext{
${ }^{12}$ Recommendation of the European Parliament and of the Council of 30 May 2002 concerning the implementation of Integrated Coastal Zone Management in Europe. OJ L148, 6 June 2002, pp.24-27. http://data.europa.eu/eli/reco/2002/413/oj
} 
contributing to the sustainable use of marine goods and services by present and future generations". The MSFD identifies MSP as a tool to support the ecosystembased management of human activities in order to achieve GES, which is a point reiterated in Recital 22 (Preamble) of the MSP Directive.

The principles and procedures involved in implemented Integrated Coastal Management, Maritime Spatial Planning and the Ecosystem Approach are broadly similar and each have the ultimate aim of delivering sustainable development (see Le Tissier 2020). All advocate the need for more holistic, integrated and adaptive management moving away from sectoral approaches, increased stakeholder participation, better use of scientific data and knowledge and integrated monitoring to adapt management actions. The challenges arising are that all approaches can be applied at different scales, however, the ecosystem approach is more suited to the ecosystem scale whereas ICM and MSP will most likely to tailored to the scale of the management problems they seek to address which may not necessarily correspond to the ecosystem level. Whilst the principles are similar the approaches differ and accordingly there is a need for greater policy coherence that takes into account a wider range of economic, environmental and social aspects. The policies adopted need to secure the delivery of ecosystem and harmonise management and conservation objectives, both in the immediate and longer term. ICM is not a binding legal requirement on all EU Member States although the 2002 ICZM Recommendation remains valid. MSP is only in the initial stages of implementation in the majority of coastal Member States hence how the Ecosystem Approach and ecosystem services will be reflected in final plans remains to be seen. It is probable that the marine strategies developed by Member States to meet the requirements of the MSFD are more likely to be ecosystem-based than either MSP or ICM given their focus but this goes to reaffirm the need for policy coherence if the ecosystem approach is to be implemented across the entire aquatic area.

\section{Discussion}

The preceding sections demonstrate that the Ecosystem Approach and ecosystem services have been incorporated into EU law and policy to varying extents. At the international level this has also continued to progress but the variety of definitions and methodologies for implementation of the concepts at the global level has very real implications for other governance scales, including regional, national and local implementation which are more utilised for aquatic management under EU law. It has been long recognised (e.g. Scheiber 1997) that there is a critical need for clarity on what EBM actually requires and how progress on implementation can be measured. The commitment to implementing EBM at EU level requires more joint implementation of legal instruments to take account of the necessary move away from management according to administrative boundaries. This is central to the WFD and echoed in the MSFD yet despite having a Common Implementation Strategy there are significant disconnects between both instruments. For example, 
marine litter is one of the descriptors used for determining GES under MSFD but there is no equivalent in the WFD, even though the majority of marine litter derives from the land as scientific evidence confirms. From a governance perspective there is a need for institutional structures that facilitate cross-sectoral management and decision-making. Competences for aquatic management are split according to the land and sea, jurisdictional boundaries and also sectorally which goes against the principles of ecosystem-based management. The same is true for monitoring, enforcement and compliance actions.

Many existing EU policies in their current form contradict the commitment to implementing EBM and preserving ecosystem services, such as measures and activities under CAP and CFP. The Fitness Check (EC 2016a, p. 91) of the nature conservation legislation found that EU financial support applies to agriculture and forestry, the main land uses in Natura 2000 as well as to prevent damage caused by protected species (e.g. under rural development for large carnivores) or to compensate for such damages (e.g. under fisheries policy for fish-eating birds). Figure 1 illustrates the levels of agricultural, fisheries and conservation across the EU. The main beneficiaries of financial support in the EU remain the economic sectors of fishing and agriculture. The overall EU co-funding for Natura 2000 during the 2007-2013 period represented only 9-19\% of the estimated financing needs and national co-funding was unable to cover the remaining gap. This could lead one to question the commitment to halting the loss of biodiversity and the degradation of ecosystem services in the EU by 2020. Alternatively, it could signal the need to better consider trade-offs in management processes. There is no 'recipe' for balancing conservation and development but it is essential that we understand who will benefit and who will lose out if ecosystem services change. This necessitates better understanding of ecosystem services. From a societal perspective, greater stakeholder participation is required so as to understand their interests and expectations. In theory, in this way more suitable interventions could be made to deliver sustainable development.

\section{Conclusions}

The European Commission has endorsed the United Nations' Sustainable Development Goals (SDGs). Effective implementation of the SDGs will require fully coordinated policies that take into account the multiple relationships that exist between the different dimensions of sustainability, something that cannot be achieved currently given the preponderance of sectoral legislation, policies and associated institutional structures. The Marine Strategy Framework Directive has the ecosystem approach at its core but implementation of its objectives is largely left up to Member States themselves, whilst other legislation and policies refer to EA but it is not the overarching objective or priority for implementation. There will always be trade-offs between conservation and development and no form of decisionmaking will make this disappear. Attaining societal agreement on long-term goals 


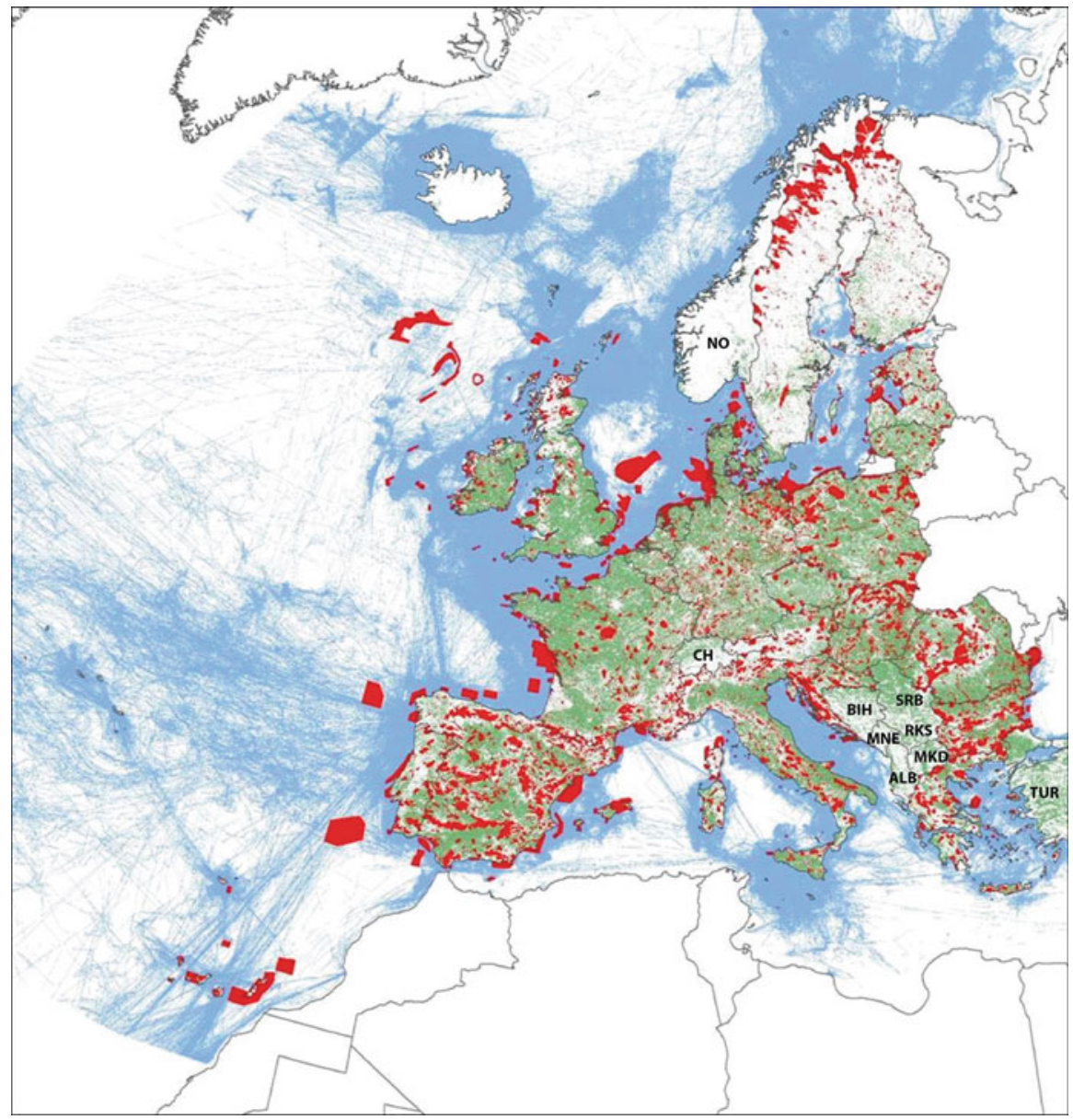

Fig. 1 Fishing vessel activity (blue), agriculture (green) and nature conservation (red) across the EU. Countries marked with ISO country codes are non-EU member states and do not participate in the EU Natura 2000 network, but have habitat data available under the Corine Land Cover inventory. Cartography by Tim O'Higgins

requires appropriate institutional mechanisms and these also need to acknowledge that societal goals change over time. Decision-making structures are still dominated by sectoral interests. This is clearly evident in the case of both the CFP and CAP. Reform of the CFP, for example, resulted in the creation of Advisory Councils as stakeholder bodies to address issues associated with participatory democracy (European Commission 2009). No measures affecting fishing activity can be adopted without reference to these Advisory Councils. Article 45(1) and Annex III (2) of Regulation 1380/2013 provides that $60 \%$ of the seats on the Advisory Councils are allocated to organisations representing the fisheries, processing and 
marketing sectors, with the remainder allocated to other interest groups. Wakefield (2019) states that the European Parliament had called for half the seats on the Advisory Councils to be reserved for interested parties outside the fishing industry but this was not accepted by the Member States in Council.

Like EBM, the conceptual basis for ecosystems services has been well expressed but implementation remains variable, perhaps explained by lack of agreement on definitions and uncertainties around the links between biodiversity and the services that flow from ecosystems. Each different ecosystem service also has a different legal status, some being public and others private. In effect, this means that rights will be held by individuals, groups, and the state, with further complexity arising between land and aquatic space and in transboundary contexts. Many of the SDGs are underpinned by the delivery of one or more ecosystem services, meaning policymakers will need to manage for multiple ecosystem services, which cannot be achieved if a single policy 'lens' is taken. Neither EA or ecosystem services alone will be sufficient to deliver on all the SDGs, but will involve concerted efforts from the spheres of institutions, technology, science, politics and society generally. The effective implementation of EBM and ecosystem services is contingent on the necessary legal and regulatory frameworks being in place. Whilst there have been attempts to incorporate both concepts into the law and policy framework there is still a large degree of contradiction in terms of over-arching objectives and goals of many key instruments. Until these are resolved, EBM in Europe will continue to be an aspirational concept rather than a tangible and effective management approach.

Acknowledgement This contribution is based upon works supported by the Navigate project (Grant-Aid Agreement No. 842 PBA/IPG/17/01), carried out with the support of the Marine Institute and funded under the Marine Research Programme by the Irish Government, and by MaREI: the SFI Research Centre for Energy, Climate and Marine (12/RC/2302).

\section{References}

Bastmeijer, K. (2019). The ecosystem approach for the marine environment and the position of humans: Lessons from the EU natura 2000 regime. In D. Langlet \& R. Rayfuse (Eds.), The ecosystem approach in ocean planning and governance: Perspectives from Europe and beyond. Leiden and Boston: Brill Nijhoff.

Berg, T., Fürhaupter, K., Teixeira, H., Uusitalo, L., \& Zampoukas, N. (2015). The marine strategy framework directive and the ecosystem-based approach-pitfalls and solutions. Marine Pollution Bulletin, 96(1-2), 18-28. https://doi.org/10.1016/j.marpolbul.2015.04.050.

Bouwma, I., Schleyer, C., Primmer, E., Winkler, K. J., Berry, P., Young, J., Carmen, E., Špulerová, J., Bezák, P., Preda, E., \& Vadineanu, A. (2018). Adoption of the ecosystem services concept in EU policies. Ecosystem Services, 29, 213-222. https://doi.org/10.1016/j.ecoser.2017.02.014.

Committee of the Regions. (2013). Opinion of the committee of the regions on proposed directive for maritime spatial planning and integrated coastal management (2013/C 356/18). OJEU, C356, 124-132. Retrieved from https://eur-lex.europa.eu/LexUriServ/LexUriServ.do?uri=OJ: C:2013:356:0124:0132:EN:PDF. 
Convention on Biological Diversity Decision V6 of the Conference of the Parties to the CBD. (2000). $5^{\text {th }}$ Meeting, Nairobi, Kenya, May 15-26, UNEP/COP/5/23. Retrieved from https:// www.cbd.int/decision/cop/default.shtml?id=7148.

Convention on Biological Diversity Decision X/2 Annex of the Conference of the Parties to the CBD. (2010). $10^{\text {th }}$ Meeting, Nagoya, Aichi Prefecture, Japan, October 18-29, UNEP/CBD/ COP/10/27. Retrieved from https://www.cbd.int/decision/cop/default.shtml?id=12268.

EEA. (2010). EU 2010 biodiversity baseline EEA Report No. 12/2010 EEA, Denmark. Retrieved from https://www.eea.europa.eu/publications/eu-2010-biodiversity-baseline.

EEA. (2015a). State of nature in the EU: Results from reporting under the nature directives 2007-2012. EEA Technical Report No. 2/2015 EEA, Denmark. Retrieved from https://www. eea.europa.eu/publications/state-of-nature-in-the-eu.

EEA. (2015b). Spatial analysis of marine protected areas in Europe's seas. EEA Technical Report No. 17/2015 EEA, Denmark. Retrieved from https://www.eea.europa.eu/publications/spatialanalysis-of-marine-protected.

Enright, S.R., \& Boetler, B. (2020). The ecosystem approach in international law. In T. O'Higgins, M. Lago, \& T. H. DeWitt (Eds.), Ecosystem-based management, ecosystem services and aquatic biodiversity: Theory, tools and applications (pp. 333-352). Amsterdam: Springer.

European Commission. (2005). Proposal for a Directive of the European Parliament and of the Council establishing a framework for community action in the field of marine environmental policy (marine strategy directive). COM, 505 final. EC, Brussels, Belgium, pp. 2-3. Retrieved from https://eur-lex.europa.eu/legal-content/EN/TXT/?uri=CELEX:52005PC0505.

European Commission. (2007). Guidelines for the establishment of the Natura 2000 network in the marine environment. EC, Brussels, Belgium. Retrieved from https://ec.europa.eu/environment/ nature/natura2000/marine/docs/marine_guidelines.pdf.

European Commission. (2009). Green paper on the reform of the common fisheries policy. COM, 163. Retrieved from https://eur-lex.europa.eu/LexUriServ/LexUriServ.do? uri=COM:2009:0163:FIN:EN:PDF.

European Commission. (2010). Commission decision of 1 September 2010 on criteria and methodological standards on good environmental status of marine waters (2010/477/EU). Official Journal of the European Union, L232(14), 14-24.

European Commission. (2011). Communication from the commission to the European parliament, the council, the economic and social committee and the committee of the regions. Our life insurance, our natural capital: An EU biodiversity strategy to 2020. COM, 0244 final. EC, Brussels, Belgium.

European Commission. (2012). Commission staff working document: The fitness check of EU freshwater policy. SWD, 393 final. EC, Brussels, Belgium, p. 10. Retrieved from https://ec. europa.eu/environment/water/blueprint/pdf/SWD-2012-393.pdf.

European Commission. (2013a). Overview of CAP reform 2014-2020. Agricultural policy perspectives brief No. 5, December. EC, Brussels, Belgium. Retrieved from https://ec.europa.eu/ agriculture/sites/agriculture/files/policy-perspectives/policy-briefs/05_en.pdf.

European Commission. (2013b). Proposal for a Directive of the European Parliament and of the Council establishing a framework for maritime spatial planning and integrated coastal management. COM, 133 final. Retrieved from https://ec.europa.eu/environment/iczm/pdf/Proposal_en. pdf.

European Commission. (2015a). Report from the Commission to the European Parliament and the Council-the Mid-term Review of the EU biodiversity strategy to 2020. EC, Brussels, Belgium. Retrieved from https://ec.europa.eu/environment/nature/biodiversity/strategy/index_en. htm\#mid.

European Commission. (2015b). Report from the Commission to the European Parliament and the Council on the progress in establishing marine protected areas (as required by Article 21 of the Marine Strategy Framework Directive 2008/56/EC). Retrieved from https://ec.europa.eu/envi ronment/marine/eu-coast-and-marine-policy/implementation/pdf/marine_protected_areas.pdf. 
European Commission. (2016a). Commission Staff Working Document Fitness Check of the EU Nature Legislation (Birds and Habitats Directives) Directive 2009/147/EC of the European Parliament and of the Council of 30 November 2009 on the conservation of wild birds and Council Directive 92/43/EEC of 21 May 1992 on the conservation of natural habitats and of wild fauna and flora. SWD, 472 final. EC, Brussels, Belgium. Retrieved from https://ec.europa. eu/environment/nature/legislation/fitness_check/docs/nature_fitness_check.pdf.

European Commission. (2016b). Special eurobarometer 440: Europeans, agriculture and the CAP. Survey requested by the European Commission, Directorate-General for Agriculture and Rural Development and co-ordinated by the Directorate-General for Communication. https://doi.org/ 10.2762/03171. Retrieved from http://ec.europa.eu/commfrontoffice/publicopinion/index.cfm/ ResultDoc/download/DocumentKy/69756.

European Commission. (2019). Evaluation study of the impact of the CAP on climate change and greenhouse gas emissions: Final Report. https://doi.org/10.2762/54044. Retrieved from https:// ec.europa.eu/agriculture/sites/agriculture/files/evaluation/market-and-income-reports/2019/capand-climate-evaluation-report_en.pdf.

European Parliament and European Council. (2013). Decision No. 1386/2013/EU of the European Parliament and of the Council of 20 November 2013 on a General Union Environment Action Programme to 2020 'Living well, within the limits of our planet' [Annex para.21 (p. 179)]. Official Journal of the European Union L, 354, 171-200. Retrieved from https://eur-lex.europa. eu/legal-content/EN/LSU/?uri=CELEX:32013D1386.

Helsinki and OSPAR Commissions. (2003). First Joint Ministerial Meeting of the Helsinki and OSPAR Commissions (JMM) Bremen Germany 25-26 June 2003, Statement on the Ecosystem Approach to the Management of Human Activities "Towards an Ecosystem Approach to the Management of Human Activities” Annex 5 Ref. §6.1. Retrieved from https://www.ospar.org/ site/assets/files/1232/jmm_annex05_ecosystem_approach_statement.pdf.

ICES. (2005). Guidance on the application of the ecosystem approach to management of human activities in the European marine environment ICES cooperative research report no. 273. https:// doi.org/10.17895/ices.pub.5477.

Le Tissier, M. (2020). Unravelling the relationship between ecosystem-based management, integrated coastal zone management and marine spatial planning. In T. O'Higgins, M. Lago, \& T. H. DeWitt (Eds.), Ecosystem-based management, ecosystem services and aquatic biodiversity: Theory, tools and applications (pp. 403-416). Amsterdam: Springer.

Long, R. (2012). Legal aspects of ecosystem-based marine management in Europe. In A. Chircop, M. L. McConnell, \& S. Coffen-Smout (Eds.), Ocean yearbook (Vol. 26, pp. 417-484). Boston: Brill Academic Publishers.

Pe'er, G., Zinngrebe, Y., Hauck, J., Schindler, S., Dittrich, A., Zingg, S., Tscharntke, T., Oppermann, R., Sutcliffe, L. M., Sirami, C., Schmidt, J., Hoyer, C., Schleyer, C., \& Lakner, S. (2017). Adding some green to the greening: Improving the EU's ecological focus areas for biodiversity and farmers. Conservation Letters, 10, 517-530. https://doi.org/10.1111/conl. 12333.

Pe'er, G., Zinngrebe, Y., Moreira, F., Sirami, C., Schindler, S., Müller, R., Bontzorlos, V., Clough, D., Bezák, P., Bonn, A., Hansjürgens, B., Lomba, A., Möckel, S., Passoni, G., Schleyer, C., Schmidt, J., \& Lakner, S. (2019). A greener path for the EU common agricultural policy. Science, 365(6452), 449-451. https://doi.org/10.1126/science.aax3146.

Rouillard, J., Lago, M., Abhold, K., Röschel, L., Kafyeke, T., Mattheiß, V., \& Klimmek, H. (2018). Protecting aquatic biodiversity in Europe: How much do EU environmental policies support ecosystem-based management? Ambio, 47, 15-24. https://doi.org/10.1007/s13280-017-0928-4.

Scheiber, H. N. (1997). From science to law to politics: An historical view of the ecosystem idea and its effects on resource management. Ecology Law Quarterly, 24(4), 631-651. https://doi. org/10.15779/Z385V74.

United Nations. (1972). Report of the United Nations Conference on the Human Environment Stockholm Sweden 5-June 16. UN Doc.A/Conf.49/14/Rev.1 Chapter 1 (Principles). Retrieved from https://www.un.org/ga/search/view_doc.asp?symbol=A/CONF.48/14/REV.1. 
Wakefield, J. (2019). The ecosystem approach and the common fisheries policy. In D. Langlet \& R. Rayfuse (Eds.), The ecosystem approach in ocean planning and governance: Perspectives from Europe and beyond. Leiden: Brill Nijhoff.

Open Access This chapter is licensed under the terms of the Creative Commons Attribution 4.0 International License (http://creativecommons.org/licenses/by/4.0/), which permits use, sharing, adaptation, distribution and reproduction in any medium or format, as long as you give appropriate credit to the original author(s) and the source, provide a link to the Creative Commons licence and indicate if changes were made.

The images or other third party material in this chapter are included in the chapter's Creative Commons licence, unless indicated otherwise in a credit line to the material. If material is not included in the chapter's Creative Commons licence and your intended use is not permitted by statutory regulation or exceeds the permitted use, you will need to obtain permission directly from the copyright holder.

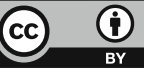

